\title{
Implementasi Subrogasi dengan Lastgeving Sebagai Instrument Hukum Dalam Peralihan Hak Atas Tanah
}

\author{
Yunesha Ratih Fitriani \\ Magister Kenotariatan Fakultas Hukum Universitas Islam Indonesia \\ Jl. Cik Di Tiro No. 1 Yogyakarta \\ yunesha@yahoo.co.id
}

\begin{abstract}
The focus of this study is to explain the implications of their subrogation by granting power of attorney involved in the transition lastgeving land rights and outlining efforts to settle the implications of the implementation of the application of subrogation by giving power of attorney lastgeving in the turnover of land rights. This research is a normative approach doctrinal and non-doctrinal. Results showed positive implications, namely the debt of the debtor be paid, the creditor will obtain repayment of debt and the third party will acquire the land and building. The implication negative is about the costs, expenses and Roya who from the beginning was not discussed so that a dispute exists between the seller and the buyer, not made a deed of power of a debt by a notary during the process of debt repayment in the bank, bad credit by the purchaser which replaced debtors, banks that do not receive transition without notice to the bank first. For his efforts in general notary prepare and notify to the parties to the costs of the burden of transition, the cost Roya, on payment of taxes, as well as supplies of administration, and the notary from the beginning to tell and gives advice on the consequences that ensue for the switchover without the knowledge of the bank so that no losses of the parties in the future.
\end{abstract}

Keywords: Subrogation, Authorization Deed Lastgeving, Transfer of Rights to Land

\begin{abstract}
Abstrak
Fokus penelitian ini adalah untuk menjelaskan implikasi dari adanya subrogasi dengan pemberian surat kuasa lastgeving terkait dalam peralihan hak atas tanah dan menguraikan upaya penyelesaian terhadap implikasi dalam pelaksanaan penerapan subrogasi melalui pemberian surat kuasa lastgeving dalam peralihan hak atas tanah. Penelitian ini adalah penelitian normatif dengan menggunakan pendekatan doktrinal dan non doctrinal. Hasil penelitian menunjukkan, Implikasi Positif, yaitu hutang debitur menjadi lunas, bagi pihak kreditur akan mendapatkan pelunasan hutang dan pihak ketiga akan mendapatkan tanah beserta bangunan. Implikasi negatifnya adalah tentang biaya-biaya, beban-beban dan roya yang dari awal tidak dibicarakan sehingga timbul perselisihan antara penjual dan pembeli, tidak dibuatkan akta kuasa pelunasan hutang oleh notaris pada saat proses pelunasan hutang di bank, terjadinya kredit macet oleh pihak pembeli yang menggantikan debitur, pihak bank yang tidak menerima peralihan tanpa pemberitahuan kepada pihak bank terlebih dahulu. Sebagai upayanya pada umumnya notaris mempersiapkan dan memberi tahu kepada para pihak tentang biaya-biaya beban peralihan, biaya roya, mengenai pembayaran pajak, serta perlengkapan administrasi, dan notaris sejak awal memberi tahu dan memberi saran mengenai akibat yang timbul terhadap peralihan tanpa sepengetahuan pihak bank sehingga tidak terjadi kerugian para pihak dikemudian hari.
\end{abstract}

Kata-kata kunci: Subrogasi, akta kuasa lastgeving, peralihan hak atas tanah 


\section{Pendahuluan}

Negara kesatuan Republik Indonesia yang berdasarkan UUD 1945 adalah negara hukum yang memberikan jaminan dan memberikan perlindungan atas hak-hak warga negara, antara lain hak warga negara untuk mendapatkan, mempunyai dan menikmati hak milik, salah satunya adalah hak milik atas tanah. ${ }^{1}$

UUPA Pasal 20 merumuskan bahwa hak milik atas tanah adalah hak yang turun temurun, terkuat dan terpenuh. Bahwa hak milik merupakan hak yang kuat, berarti hak itu tidak mudah hapus dan mudah dipertahankan terhadap gangguan pihak lain. ${ }^{2}$ Hak milik dapat beralih dan dialihkan, beralih adalah pindahnya hak milik kepada pihak lain bukan karena perbuatan hukum yang disengaja, akan tetapi karena hukum dengan sendirinya, karena pewarisan. Jadi dengan meninggalnya pemilik tanah maka tanah tersebut dengan sendirinya, karena hukum akan jatuh/pindah kepada ahli warisnya.

Dialihkan adalah pindahnya hak milik kepada pijak lain karena adanya perbuatan hukum yang disengaja. Jadi untuk beralihnya atau pindahnya hak milik tersebut kepada pihak lain harus ada perbuatan tertentu yang memang sengaja untuk mengalihkan hak milik tersebut, peralihan hak yang dimaksudkan terjadi baik karena jual beli, pelepasan hak, maupun karena suatu perjanjian pemberian pembebanan sebagai ikutan perjanjian hutang. Setiap peralihan maupun pembebanan hak-hak atas tanah, baik hak milik maupun hak atas tanah lainya yang dapat dialihkan kepada pihak lain, atau dibebani haknya maka dalam peraturan undang-undang wajib didaftarkan. ${ }^{3}$

Peralihan hak atas tanah dengan cara jual beli terjadi antara 2 (dua) pihak yaitu pihak penjual sebagai pemegang hak atas tanah menjual kepada pihak lainya yaitu pembeli yang berkeinginan memiliki/mempunyai hak atas tanah tertentu. Adapun pendaftaran peralihan hak-hak atas tanah sebagaimana, diatur lebih lanjut pada pasal 37 ayat (1) PP No. 24 Tahun 1997 yang menetapkan: "peralihan hak atas tanah dan hak milik atas satuan rumah susun melalui jual beli, tukar-menukar, hibah, pemasukkan dalam perusahaan dan perbuatan hukum pemindahan hak lainnya, kecuali pemindahan hak melalui lelang hanya dapat didaftarkan jika dibuktikan dengan akta yang dibuat oleh PPAT yang berwenang menurut ketentuan perturan perundang-undangan yang berlaku. ${ }^{4}$

\footnotetext{
${ }^{1}$ Adrian Sutedi, Peraliban Hak. Atas Tanah dan Pendaftarannya, Sinar Grafika, Jakarta, 2007.hlm.1

2 Pasal 20 UUPA

3 Olan Sitorus dan H.M. Zaki Sierrad, Hukum Agraria di Indonesia Konsep Dasar dan Implementasi, Mitra Kebijakan Tanah Indonesia, Yogyakarta, 2006. 102.

${ }^{4}$ Peraturan Pemerintah Republik Indonesia No.24 Tahun 2007 tentang Pendaftaran Tanah, Pasal. 37
} 
Ketentuan tersebut menunjukan bahwa salah satu perbuatan hukum yang menyebabkan terjadinya peralihan hak atas tanah dan harus didaftarkan balik namanya adalah perbuatan hukum jual beli yang aktanya dibuat dalam bentuk akta jual beli yang dibuat dihadapan Pejabat Pembuat Akta Tanah (PPAT).

Dalam peralihan hak atas tanah dengan cara jual beli dapat dilakukan yaitu secara terang dan tunai dalam artian pembayaran jual beli hak milik atas tanah dilakukan pada saat bersamaan dihadapan PPAT, ${ }^{5}$ dalam peralihan hak atas tanah juga pembayarannya dapat dilakukan dengan cara tidak lunas, pembayaran dengan kredit dibank, kredit yang disalurkan oleh bank merupakan kepercayaan yang diberikan kepada debitur untuk pembiayaan, konsumtif dan usaha yang pembayaran atau pelunasannya diatur dengan syarat-syarat dan kesepakatan bersama didalam bentuk perjanjian kredit. Namun kredit hanya dapat diberikan apabila adanya jaminan. ${ }^{6}$

Adanya jaminan dalam pemberian kredit ini diatur dalam Undang-Undang Nomor 10 tahun 1998 tentang perbankan, namun istilah yang digunakan dalam Undang-Undang yang menunjuk pada jaminan adalah agunan, beberapa jaminan yang digunakan dalam pemberian kredit oleh bank salah satunya adalah dengan Hak Tanggungan yang dikhususkan pada objek tanah beserta benda yang berkaitan dengan tanah. ${ }^{7}$

Pasal 1 Angka 1 UU No.4 Tahun 1996 tentang Hak Tanggungan Atas Tanah Beserta Benda-benda yang berkaitan dengan Tanah (UUHT) memberikan pengertian mengenai Hak Tanggungan, yaitu: Hak tanggungan atas tanah beserta benda-benda yang berkaitan dengan tanah, yang selanjutnya disebut Hak Tanggungan, adalah hak jaminan yang dibebankan pada hak atas tanah sebagaimana dimaksud dalam undang-undang Nomor 5 Tahun 1960 tentang Peraturan Dasar Pokok-pokok Agraria, berikut atau tidak berikut benda-benda lain yang merupakan satu kesatuan dengan tanah itu, untuk pelunasan utang tertentu, yang memberikan kedudukan yang diutamakan kepada kreditur tertentu terhadap krediturkreditur lain. ${ }^{8}$

Dalam praktek sering kali terjadi peralihan objek jaminan yang merupakan hak tanggungan, peralihan terhadap hak tanggungan tersebut diatur dalam Pasal 16 sampai dengan Pasal 17 Undang-Undang Tahun 1996. Peralihan hak tanggungan dapat dilakukan

\footnotetext{
${ }^{5}$ Gunawan Widjaya dan Kartini Mulyadi, Jual Beli, Raja Grafindo Persada, Jakarta, 2003, hlm. 87

${ }^{6}$ Abdul Kadir, Hukum Perdata Indonesia, Citra Aditya Bakti, Bandung, 1990, hlm. 181

${ }^{7}$ Hendrik Budi Untung, Kredit Perbankan di Indonesia (edisi KeII), Andi Offset, Yogyakarta, 2011, hlm .1

${ }^{8}$ Undang-Undang No. 4 Tahun 1996 Tentang Hak Tanggungan atas Tanab beserta Benda-Benda yang berkaitan dengan Tanah, Lembaran Republik Indonesia tahun 1996 No.42 dan Tambahan Lembaran Negara tahun 1996 No. 3632. Pasal 1 angka 1.
} 
dengan cara cessi, subrogasi, pewarisan dan sebab-sebab lainnya. Subrogasi diatur dalam Pasal 1400 KUHPerdata dijelaskan bahwa: Subrogasi adalah penggantian kedudukan kreditur oleh pihak ketiga. Penggantian itu terjadi dengan pembayaran yang diperjanjikan ataupun karena ditetapkan oleh undang-undang. ${ }^{9}$

Perbuatan hukum pengalihan objek jaminan dengan cara subrogasi ini salah satunya adalah terjadinya peralihan objek jaminan KPR yang masih dalam masa KPR kepada pihak lain oleh debitur atau yang sering dikenal dengan istilah take over kredit, sebagian besar yaitu dibuat dalam bentuk perjanjian pengikatan jual-beli dengan kuasa menjual antara pihak lain sebagai pihak penerima pengalihan hak kredit pemilikan tanah dan rumah (KPR) yang dilakukan dihadapan pejabat yang berwenang adalah Notaris.

Perjanjian pengikatan jual beli menurut R. Subekti dalam bukunya adalah perjanjian antar pihak penjual dan pihak pembeli sebelum dilaksanakannya jual beli dikarenakan adanya unsur-unsur yang harus dipenuhi untuk jual-beli tersebut antara lain adalah sertipikat belum ada karena masih dalam proses, belum terjadinya pelunasan harga. ${ }^{10}$

Untuk menjamin hak-hak pihak pembeli dan menghindari terjadinya kerugian terhadap perjanjian jual beli ini, karena terjadinya sesuatu dan lain hal dikemudian hari maka sebaiknya perjanjian jual beli ini dalam isi pokoknya dibuat syarat-syarat atau ketentuanketentuan lainnya yang dipandang perlu dan disepakati oleh para pihak, satu dan lain sepanjang syarat-sayarat tersebut tidak bertentangan dengan hukum yang berlaku. ${ }^{11}$

Salah satu syarat atau ketentuan tersebut adalah dengan pemberian kuasa, misalnya adalah kuasa pengambilan sertipikat dibank, kuasa untuk menjual kepada calon pembeli, dan kuasa pelunasan hutang, yang diberikan oleh calon penjual kepada calon pembeli. Dapat kita fahami pemberian kuasa tersebut tidak berdiri sendiri, sekalipun mungkin dibuat dalam akta yang terpisah, sebab pemberian kuasa ini merupakan salah satu isi dan merupakan satu kesatuan yang tidak terpisahkan dari ikatan jual beli.

Untuk menjamin adanya kepastian hukum maka sebaiknya dan selayaknya perjanjian ini dibuat secara tertulis dalam bentuk bukan akta otentik atau dengan akta otentik. Mengenai perjanjian ini adalah merupakan perjanjian pemberian kuasa lastgeving oleh calon penjual kepada calon pembeli dimana mengikat pada perjanjian pokoknya yaitu perjanjian jual beli atau yang disebut dengan pactum the contrahendo.

${ }^{9}$ Mariam Darus Badrul Zaman, et. Al; Kompilasi Hukum Perikatan Dalam Rangka Memperingati Memasuki Masa Purna Bakti Usia 70 Tahun, Citra Aditya Bakti, Bandung, 2001, hlm.126

${ }_{10}$ R. Subekti, Hukum Perjanjian, Intermasa, Jakarta, 1998, hlm.75

11 Agus Pandoman, Rangkuman Intisari Sistem Hukum Perikatan BW dan Islam, Diktat 2016,Yogyakarta,hlm.136 
Pemberian kuasa dengan cara lastgeving dalam perjanjian jual beli ini adalah merupakan instrument dari lavering, karena dalam perjanjian jual beli ini belum terjadi pemindahan hak milik, adapun hak milik baru berpindah ketika telah dilakukan penyerahan sertifikat yang masih dalam jaminan dibank. Sedangkan pembayaran dalam perjanjian ini sudah dilakukan oleh pihak ketiga kepada pihak debitur atau obligatoir nya sudah terjadi, artinya bahwa: "Perjanjian jual beli baru meletakkan hak dan kewajiban timbal balik antara kedua belah pihak (penjual dan pembeli)" yaitu meletakkan kepada penjual kewajiban untuk menyerahkan hak milik atau barang yang dijualnya, sekaligus memberikan kepadanya hak untuk menuntut pembayaran harga yang telah disetujui, dan di sebelah lain meletakkan kewajiban kepada pembeli untuk membayar harga barang sebagai imbalan haknya untuk menuntut penyerahan hak milik atas barang yang telah dibelinya (lavering).

Pemberian kuasa dengan cara lastveging (lastgeving) diatur dalam Buku III-Bab XVI, mulai pasal 1792 sampai dengan pasal 1819, (lastgeving) adalah: "suatu perjanjian dengan mana seorang memberikan kekuasaan kepada orang lain yang menerimanya, untuk dan atas namanya menyelenggarakan suatu urusan". Dalam pemberian kuasa dengan cara lastgeving juga harus memenuhi rumusan mengenai sahnya suatu perjanjian, sahnya suatu perjanjian berdasarkan Pasal 1320 KUHPerdata yaitu: 1. Kesepakatan mereka yang mengikatkan dirinya; 2. ecakapan untuk membuat suatu perikatan; 3. Suatu pokok persoalan tertentu; 4. Suatu sebab yang tidak terlarang

Dalam pemberian kuasa dengan cara lastgeving juga secara materiil mengikat para pihak yang membuatnya Pasal 1338 KUHPerdata sebagai suatu perjanjian yang harus ditepati oleh para pihak (pacta sunt servada). ${ }^{12}$

Dalam Pasal 1 angka 1 Undang-Undang Jabatan Notaris, Notaris adalah pejabat umum yang berwenang untuk membuat akta otentik dan memiliki kewenangan lainnya sebagaimana dimaksud dalam undang-undang ini atau berdasarkan undang-undang lainnya. Dalam pasal 15 ayat (1) Undang-Undang Nomor 2 Tahun 2014 tentang jabatan notaris (UUJN) merupakan sumber kewenangan notaris dalam melaksanakan tugas jabatannya.

Pasal 15 ayat (1) mengatur bahwa notaris berwenang membuat akta otentik mengenai semua perbuatan, perjanjian, dan penetapan yang diharuskan oleh peraturan per undang-undangan dan/ atau yang dikehendaki oleh yang berkepentingan untuk dinyatakan dalam akta otentik, menjamin kepastian tanggal pembuatan akta, menyimpan akta,

12 Habieb Adjie, Hukum Notaris Indonesia (Tafsir Tematik Terbadap UU No. 30 Tabun 2004 tentang Jabatan Notaris), PT. Refika Aditama, Bandung, 2011, hlm. 197 


\section{LEX Renaissance No. 1 VOL. 2 JANUARI 2017: 85 - 95}

memberikan grosse, salinan dan kutipan akta, semuanya itu sepanjang pembuatan akta-akta itu tidak juga ditugaskan atau dikecualikan kepada pejabat lain atau orang yang ditetapkan undang-undang.

Dalam prakteknya peralihan hak tanggungan dengan cara subrogasi dengan pemberian kuasa lastgeving yang dibuat secara otentik oleh notaris, tidak selamanya dapat berjalan sesuai dengan yang diinginkan para pihak dalam perjanjian jual beli tersebut. Dalam kondisi-kondisi tertentu dapat ditemukan terjadinya berbagai masalah dan problem bagi para pihak sehingga sampai menimbulkan kerugian bagi para pihak.

\section{Rumusan Masalah}

Berdasarkan latar belakang masalah yang telah diuraikan diatas maka dapat dirumuskan identifikasi masalah yaitu apakah implikasi dari adanya subrogasi dengan pemberian surat kuasa lastgeving terkait dalam peralihan hak atas tanah dan Bagaimanakah upaya penyelesaian terhadap implikasi dalam pelaksanaan penerapan subrogasi melalui pemberian surat kuasa lastgeving dalam peralihan hak atas tanah?

\section{Tujuan Penelitian}

Penelitian ini bertujuan untuk mengkaji dan menjelaskan mengenai implikasi dari adanya subrogasi dengan pemberian surat kuasa lastgeving terkait dalam peralihan hak atas tanah serta untuk mengkaji dan menjelaskan mengenai upaya penyelesaian terhadap implikasi dalam pelaksanaan penerapan subrogasi melalui pemberian surat kuasa lastgeving dalam peralihan hak atas tanah.

\section{Metode Penelitian}

Penelitian ini bersifat penelitian hukum normatif, yaitu peneliti pada umumnya akan menganalisis fakta-fakta atau kejadian yang relevan dengan norma-norma hukum, dengan langkah awal adalah identifikasi fakta-fakta hukum terkait dengan pelaksanaan implementasi subrogasi pelunasan hutang dengan lastgeving sebagai instrument hukum dalam peralihan hak atas tanah. Adapun jenis dan sumber data yang dipergunakan dalam penelitian ini adalah sebagai berikut: a. Sumber data primer, yaitu data yang diperoleh dengan cara wawancara dan observasi. b. Sumber data sekunder, yaitu data diperoleh melalui bahan hukum baik lisan maupun tulisan seperti, buku-buku, jurnal, makalah, majalah, Koran, dokumen, peraturan perundang-undagan. ${ }^{13}$

${ }^{13}$ M. Syamsudin, Oprasionalisasi Penelitian Hukum, PT. Raja Grafindo Persada, Jakarta, 2007, hlm. 101. 


\section{Metode Penelitian}

Teknik pengumpulan data yang digunakan dalam penelitian ini adalah: pertama, Data Primer, yakni dilakukan dengan diambil langsung oleh peneliti dari objek atau subjek penelitian yaitu wawancara kepada notaris. Kedua, Data Sekunder, yaitu bahan pustaka yang didapat tidak secara langsung dari objek penelitian, meliputi peraturan perundangundangan, majalah, disertasi atau tesis, buku-buku dan dokumen-dokumen lain yang memiliki keterkaitan dengan permasalahan yang diteliti. ${ }^{14}$ Dalam penelitian hukum terdapat beberapa pendekatan. Dengan pendekatan tersebut peneliti akan mendapatkan informasi dari berbagai aspek mengenai isu yang sedang dicoba untuk dicari jawabannya. ${ }^{15}$

Pendekatan penelitian yang digunakan dalam penulisan ini adalah pendekatan doktrinal dan non doktrinal. Pendekatan doktrinal yang digunakan dalam penelitian ini adalah pendekatan konseptual (conceptual approach). Pendekatan non doktrinal yang dimaksudkan dalam penelitian ini adalah jenis penelitian hukum normatif-empiris, yang dimaksud dengan normatif-empiris adalah suatu penelitian hukum yang meletakkan hukum sebagai sebuah bangunan system norma. Sistem norma berperan sebagai objek kajian dalam penelitian ini kemudian dipadukan dengan data pendukung berupa wawancara yang merupakan aplikasi dari penerapan norma tersebut kepada masyarakat.

Dengan perpaduan kedua metode pendekatan penelitian, yaitu doktrinal dan non doktrinal, penelitian ini diharapkan dapat memberi gambaran yang komprehensif terkait dengan subtansi penelitian. Untuk mengkaji tentang permasalahan pertama dalam penelitian ini, yaitu terkait penerapan subrogasi dengan pemberian surat kuasa lastgeving dalam peralihan hak atas tanah. Kemudian untuk mengkaji mengenai implikasi dalam pelaksanaan penerapan subrogasi dengan pemberian surat kuasa lastgeving dalam peralihan hak atas tanah maka pendekatan non doctrinal yang digunakan.

Data yang berhasil dikumpulkan dalam penelitian tersebut (baik data primer maupun data sekunder) akan dianalisis dengan menggunakan analisa kualitatif, artinya menguji data dengan konsep dan pendapat para ahli, peraturan perundang-undangan dan studi yang akhirnya menarik kesimpulan untuk menentukan hasil analisis data merupakan langkah selanjutnya untuk mengolah hasil penelitian.

14 Suratman, et. al., Metode Penelitian Hukum, Alfabeta, Bandung, 2012, hlm. 123.

15 Peter Mahmud Marzuki, Penelitian Hukum. Jakarta: Kencana, 2013, hlm. 136. 


\section{IEx Renaissance No. 1 VOL. 2 JANUARI 2017: 85 - 95}

\section{Hasil Penelitian dan Pembahasan}

Dalam subrogasi peralihan dapat terjadi dengan cara bahwa subrogasi dengan pemberian surat kuasa lastgeving terkait dalam peralihan hak atas Tanah atau take oper kredit terhadap kredit pemilikkan rumah (KPR) dapat menimbulkan implikasi, dimana implikasi tersebut dapat berupa implikasi positif dan implikasi negatif. Berikut uraian mengenai implikasi positif dan implikasi negatif:

\section{Implikasi Positif Subrogasi dengan Pemberian Surat Kuasa Lastgeving Terkait Dalam Peralihan Hak Atas Tanah Atau Take Oper Kredit}

Implikasi positif peralihan dengan subrogasi atau take oper kredit yang resmi menggunakan prosedur dari bank yaitu: 1 . Hutang debitur menjadi lunas, bagi pihak kreditur (bank) akan mendapatkan pelunasan hutang debitur dari pihak ketiga, dan pihak ketiga akan mendapatkan tanah beserta rumah yang telah dibayarkan atas nama pihak ketiga. 2. Bila pihak ketiga menggantikan debitur, maka debitur lama terbebas dari kewajibannya dan kreditur tidak dapat menagih kepada debitur lama tetapi pengaihan digantikan oleh pihak ketiga yang menjadi debitur baru. 3. Bila kreditur yang berganti, maka hak-hak kreditur lama akan hapus, dan kreditur lama tersebut tidak dapat lagi menagih kepada debitur lama. 4. Bila kreditur yang berganti, maka segala tangkisan yang semula dapat diajukan oleh debitur kepada kreditur lama, sekarang tidak dapat lagi diajukannya. ${ }^{16}$

Implikasi positif dalam peralihan dengan subrogasi atau take oper kredit yang tidak menggunkan prosedur dari bank atau tanpa sepengetahuan bank yaitu: 1. Mudah dan cepat sehingga syarat-syarat seperti yang dibuat di bank yang terasa membebani tidak perlu dipenuhi; 2. Hemat uang, dan hemat waktu, bebas dari biaya administrasi atau tidak perlu mengeluarkan dana untuk biaya peralihan kredit seperti yang resmi dari bank.

Dalam peralihan dengan subrogasi atau take oper kredit terhadap kredit pemilikkan rumah (kpr) tidak hanya menimbulkkan implikasi positif tetapi juga menimbulkan implikasi negatif yaitu sebagai berikut: 1. Implikasi Negatif Subrogasi dengan Pemberian Surat Kuasa Lastgeving Terkait Dalam Peralihan Hak Atas Tanah Atau Take Oper Kredit. 1) Apabila sejak awal para pihak yang sepakat melakukan peralihan ini tidak membicarakan biayabiaya dalam peralihan, yang mana ternyata biaya-biaya tersebut relatif mahal karena harus melalui prosedur sesuai dengan kebijaksanaan dari masing-masing bank. Misalnya pada saat roya ternyata ada beban biaya yang harus dibayarkan, tetapi didalam perjanjian awal antara pihak penjual dan pembeli tidak membahas mengenai kesepakatan siapa yang bertanggung

${ }^{16}$ J.Satrio, ...Op.Cit.hlm.124 
jawab atas pembayaran beban biaya tersebut, sehingga terjadilah perselisihan antara pihak penjual dan pembeli tadi. ${ }^{17}$ 2) Pada saat proses pelunasan ternyata ada beberapa bank yang mengharuskan menggunakan kuasa pelunasan hutang, tetapi ternyata notaris hanya membuatkan kuasa pengambilan sertifikat saja. Sehingga harus dibuatkan surat kuasa pelunasan hutang pada hari itu juga. 3) Apabila pihak bank tidak mengetahui adanya peralihan objek jaminan oleh pihak debitur (penjual) kepada pihak penerima peralihan (pembeli), dimana masalah yang muncul pada saat pembeli akan melakukan pelunasan, dalam hal ini ada pihak bank yang menerima mekanisme peralihan dengan cara ini dan menerima kuasa tadi namun ternyata ada juga pihak bank yang tidak menerima adanya pengalihan dengan mekanisme ini walaupun sudah ada surat kuasa. 4) Apabila pihak pembeli tidak dapat melanjutkan pembayaran kredit di bank, sedangkan pihak debitur (penjual) sulit ditemui akan terjadi kredit macet, maka dapat saja pihak debitur di balcklist oleh bank karena namanyalah yang tercatat sebagai pemohon kredit. Akibat dari pemblacklist-an tersebut adalah apabila mau mengajukan kredit ke bank di bank maka tidak akan diterima atau disetujui.

\section{Upaya Penyelesaian Terhadap Implikasi Dalam Pelaksanaan Penerapan Subrogasi Melalui Pemberian Surat Kuasa Lastgeving Dalam Peralihan Hak Atas Tanah}

Berdasarkan penjelasan di atas mengenai implikasi positif dan implikasi negatif dari adanya subrogasi melalui pemberian surat kuasa lastgeving dalam peralihan hak atas tanah, maka dapat dilakukan penyelesaian terhadap implikasi negatif tersebut dengan cara sebagai berikut: 1 . Mengenai biaya-biaya yang timbul dari akibat peralihan dengan cara subrogasi atau take over kredit ini, yang dari awal tidak dibicarakan sehingga terjadi perselisihan antara para pihak, menurut Fahrul Rozi, sebaikknya dilakukan dengan musyawarah untuk dilakukan kesepakatan-kesepakatan siapa yang mempunyai kewajiban-kewajiban dalam menanggung beban biaya yang timbul dari adanya peralihan tersebut. Notaris seharusnya sebagai dari awal memberikan penjelasan mengenai kewajiban-kewajiban para pihak mengenai biaya yang akan dibayarkan akibat terjadinya proses peralihan tersebut. ${ }^{18} 2$. Mengenai kuasa pelunasan hutang, pada saat proses pelunasan ternyata ada beberapa bank yang mengharuskan menggunakan kuasa pelunasan hutang, tetapi ternyata notaris hanya membuatkan kuasa pengambilan sertifikat saja. Sehingga harus dibuatkan surat kuasa

${ }^{17}$ Hasil Wawancara Kepada Yuniatri Setyastuti, Notaris-PPAT di Sleman-Yogyakarta. Tanggal 05 Januari 2017 Pukul 10.35 WIB

${ }^{18}$ Fahrul, ... Op.Cit 


\section{IEx Renaissance No. 1 VOL. 2 JANUARI 2017: 85 - 95}

pelunasan hutang pada hari itu juga. Dalam hal ini untuk penyelesaiannya adalah pihak pembeli harus menghubungi pihak penjual agar dapat dibuatkan kuasa pelunasan hutang oleh notaris yang mengurus peralihan take oper kredit tersebut. ${ }^{19} 3$. Ketika terjadinya kredit macet oleh pihak pembeli, sedangkan pihak debitur (penjual) sulit ditemui. Untuk menyelamatkan kredit ini pihak bank akan melakukan lelang terhadap objek jaminan atas hak tanggungan tersebut.

\section{Penutup}

Daeri uraian di atas Penulis menyimpulkan, 1. Implikasi subrogasi dengan pemberian kuasa lastgeving terkait dalam peralihan hak atas tanah atau take oper kredit pemilikkan rumah yaitu: a. Implikasi Positif, yaitu hutang debitur menjadi lunas, bagi pihak kreditur akan mendapatkan pelunasan hutang dan pihak ketiga akan mendapatkan tanah beserta bangunan. $b$. Implikasi negatifnya adalah tentang biaya-biaya, beban-beban dan roya yang dari awal tidak dibicarakan sehingga timbul perselisihan antara penjual dan pembeli, tidak dibuatkannya akta kuasa pelunasan hutang oleh notaris pada saat proses pelunasan hutang di bank, terjadinya kredit macet oleh pihak pembeli yang menggantikan debitur, pihak bank yang tidak menerima peralihan tanpa pemberitahuan kepada pihak bank terlebih dahulu. 2. Upaya penyelesaian terhadap implikasi dalam pelaksanaan penerapan subrogasi dengan pemberian kuasa lastgeving terkait dalam peralihan hak atas tanah atau take oper kredit pemilikkan rumah adalah dilakukan pada umumnya notaris mempersiapkan dan memberi tahu kepada para pihak tentang biaya-biaya beban peralihan, biaya roya, mengenai pembayaran pajak, serta perlengkapan administrasi, dan notaris sejak awal memberi tahu dan memberi saran mengenai akibat yang timbul terhadap peralihan tanpa sepengetahuan pihak bank sehingga tidak terjadi kerugian para pihak dikemudian hari.

Berdasarkan uraian diatas maka peneliti menyampaikan beberapa saran yaitu sebagai berikut: 1. Untuk menghindari permasalahan dikemudian hari maka bagi masyarakat yang ingin melakukan pengalihan terhadap kredit pemilikkan rumah melalui subrogasi dengan pemberian surat kuasa lastgeving sebaiknya dilakukan dengan itikad baik yaitu dengan mencari informasi proses peralihannya dengan menanyakan kepada pihak bank yang memberikan kredit mengenai prosedur peralihan dengan cara subrogasi atau take oper kredit ini yang sesuai dengan prosedur bank tersebut, agar tidak terjadi kesalahan sehingga dapat menimbulkan kerugian bagi para pihak. 2. Notaris dalam melaksanakan 
tugas dan jabatannya tidak terlepas dari taggung jawab pembuatan akta dengan baik dan benar yang memenuhi kehendak hukum dan permintaan pihak-pihak yang berkepentingan karena jabatanya, dan notaris harus dapat memberi saran atau nasihat sesuai dengan hukum dan prosedur yang berlaku.

\section{Daftar Pustaka}

\section{Buku}

Habieb Adjie, Hukum Notaris Indonesia (Tafsir Tematik Terhadap UU No. 30 Tahun 2004 tentang Jabatan Notaris), PT. Refika Aditama, Bandung, 2011

M. Syamsudin, Oprasionalisasi Penelitian Hukum, PT. Raja Grafindo Persada, Jakarta, 2007.

Mariam Darus Badrul Zaman, et. Al; Kompilasi Hukum Perikatan Dalam Rangka Memperingati Memasuki Masa Purna Bakti Usia 70 Tahun, Citra Aditya Bakti, Bandung, 2001.

Subekti, Hukum Perjanjian, Intermasa, Jakarta, 1998.

Suratman, et. al., Metode Penelitian Hukum, Alfabeta, Bandung, 2012

Peter Mahmud Marzuki, Penelitian Hukum, Jakarta: Kencana, 2013

\section{Tesis, Modul, Jurnal atau Surat Kabar}

Agus Pandoman , Modul Peraturan Primer Perikatan Akta-Akta Publisitas-Non Publisitas ( Jilid I). , Modul Peraturan Primer Perikatan Akta-Akta Publisitas-Non Publisitas ( Jilid II) , Rangkuman Intisari Sistem Hukum Perikatan BW dan Islam, Diktat 2016, Yogyakarta.

\section{Peraturan Perundang-Undangan}

Kitab Undang-Undang Hukum Perdata (Burgerlijk Wetboek), Grahamedia Press

UUJN No. 2 Tahun 2014 tentang perubahan atas Undang-Undang Nomor 30 Tahun 2004 tentang Jabatan Notaris.

Peraturan Pemerintah No.24 Tahun 1997 tentang Pendaftaran Tanah.

Peraturan Pemerintah No. 37 Tahun 1998 tentang PPAT

Undang-Undang No.4 tahun 1996 Tentang Hak Tanggungan atas Tanah beserta

Benda-Benda yang berkaitan dengan Tanah, Lembaran Republik Indonesia tahun

1996 no.42 dan Tambahan Lembaran Negara tahun 1996 No.3632. 